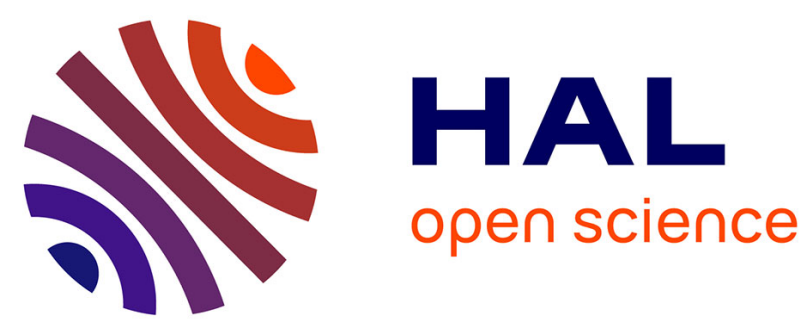

\title{
Marine protected areas: from conservation to sustainable development
}

Jean-François Noël, Jean-Yves Weigel

\section{To cite this version:}

Jean-François Noël, Jean-Yves Weigel. Marine protected areas: from conservation to sustainable development. International Journal of Sustainable Development, 2007, 10, pp.233 - 250. 10.1504/IJSD.2007.017645 . hal-01078515

\section{HAL Id: hal-01078515 https://hal.science/hal-01078515}

Submitted on 29 Oct 2014

HAL is a multi-disciplinary open access archive for the deposit and dissemination of scientific research documents, whether they are published or not. The documents may come from teaching and research institutions in France or abroad, or from public or private research centers.
L'archive ouverte pluridisciplinaire HAL, est destinée au dépôt et à la diffusion de documents scientifiques de niveau recherche, publiés ou non, émanant des établissements d'enseignement et de recherche français ou étrangers, des laboratoires publics ou privés. 


\title{
Marine protected areas: from conservation to sustainable development
}

\author{
Jean-François Noël and Jean-Yves Weigel ${ }^{*}$ \\ C3ED, Université de Versailles Saint Quentin en Yvelines, \\ 47 Boulevard Vauban, 78047 Guyancourt Cedex, France \\ E-mail: jean-francois.noel@c3ed.uvsq.fr E-mail: weigeljy@ird.fr \\ *Corresponding author
}

\begin{abstract}
After a period during which MPAs were instrumentalised as a palliative against the inadequacy of a fisheries management conventional approach, the multi-use character of these areas prevailed, conflicts were pacified by instilling a participative process and a plurality of goals is now fully recognised. Thus MPAs are becoming both a tool and a preferred context for sustainable development in its ecological, economic and social dimensions and applied through a participatory approach that entitles local communities to both create and manage this type of area. This article will discuss the full range of these changes and how MPAs' goals have evolved with time, from a priority granted to conservation to the recognition of a plurality of goals. This article will then examine to what extent the results obtained by MPAs working toward each one of these goals make them valuable examples of areas where the requirements of sustainable development are met.
\end{abstract}

Keywords: conservation; fisheries; marine protected area; sustainable development; tourism.

Reference to this paper should be made as follows: Noël, J-F. and Weigel, J-Y. (2007) 'Marine protected areas: from conservation to sustainable development', Int. J. Sustainable Development, Vol. 10, No. 3, pp.233-250.

Biographical notes: Jean-François Noël is Professor in Environmental and Natural Resources Economics. He is a member of the C3ED, a mixed research unit between IRD (French Research Institute for Development) and UVSQ (University of Versailles-Saint-Quentin en Yvelines). His present research fields are socio-economic analysis of marine protected areas and economic valuation of biological diversity resources.

Jean-Yves Weigel is a fisheries economist and a Research Director at IRD (Institut de Recherche pour le Développement). His publishing credits include thirty-three articles and five edited special issues in refereed journals. He has led many research programmes in West Africa and South East Asia and is presently leading a research programme on the evaluation of the societal cost of fisheries activities and the impact of marine protected areas in Thailand for the C3ED research unit (IRD/Université of Versailles Saint-Quentin en Yvelines).

\section{Introduction}

The changes occurring over the last few decades in what are now called marine protected areas (MPAs) provide a good example of how the sustainable development concept has spread to all sectors of the environment and society. Created initially in imitation of the 
first terrestrial natural reserves with a purely conservationist objective, MPAs quickly became highly diversified, so much so that the concept even then could appear as a catch-all concept, despite a number of inconsistencies. The extremely confining framework imposed upon these areas, which accepted no other use than conservation, often generated conflicts, revealing a plurality of uses which sought to be maintained or continued.

After a period during which MPAs were instrumentalised as a palliative against the inadequacy of the regulated management of conventional fisheries, the multi-use character of these areas prevailed, conflicts were pacified by instilling a participative process and a plurality of goals is now fully recognised. Thus, MPAs are becoming both a tool and a preferred context for sustainable development in its ecological, economic and social dimensions and applied through a participatory approach that entitles local communities to both create and manage this type of area. This article will discuss the full range of these changes. After having outlined and defined the MPA concept, we will see how MPAs' goals have evolved with time, from a priority granted to conservation to recognition of a plurality of goals. We will then examine to what extent the results obtained by MPAs working toward each one of these goals make them valuable examples of areas where the requirements of sustainable development are met.

This article is partly based on a documentary database of more then 4000 references (N'Diaye et al., 2002) and on a pre-summary document relating to a general literature review of marine and coastal protected areas (Weigel and Sarr, 2002) done within the frame of a European research project focused on the coherence of conservation and development policies for marine protected areas in West Africa, and partly based on the results of an other project focused on a comparative analysis of the societal cost of fishing activities in MPAs and in unprotected areas. ${ }^{1}$

\section{The marine protected area as a catch-all concept}

Although the term 'marine protected area' (MPA) has been in wide use for only two or three decades, the concept dates back several centuries, because marine zones whose access was prohibited or restricted by local habits or religious beliefs have always existed. Without going back that far in time, one can consider that the first modern MPA (compared with other MPAs, known as traditional MPAs) date from the 1930s, with the creation in 1935 of the Fort Jefferson Reserve in Florida, the first extension to the marine space of a concept which had proven reliable in the terrestrial field since the creation of the Yellowstone National Park in 1872.

Since then, the number of MPAs created has sharply increased, in particular during the 1970s, with a deceleration in the 1990s. However, Kelleher et al. (1995) estimated that the number of existing MPAs in the world increased from 118 in 1970 to 1306 in 1995. For the United States only, the inventory carried out within the NOAA in 2003 reports between 1000 and 1500. Although MPAs were first created in developed countries (the United States, Australia, New Zealand and European countries), developing countries also multiplied MPAs thereafter, so much so that currently half of the existing MPAs are in Asia or Oceania, the majority in tropical environments (Kelleher et al., 1995). West Africa is not left out of the picture, since the Banc d'Arguin National Park (Mauritania) was created in 1976, the Saloum Delta Biosphere Reserve (Senegal) in 1981 and the Bolama-Bijagos Archipelago Biosphere Reserve (Guinea Bissau) in 1996. 


\subsection{A generic definition}

The concept - and the precise term - of MPA appeared on the international scene in 1962, when the IUCN organised the first World Conference on National Parks in Seattle.

Many other terms have prevailed for a long time: Silva et al. (1986) indexed up to 91 different denominations. A number of generic terms can be cited - marine protected area, marine park, biosphere reserve and natural reserve - and for the particular terms implying various use restrictions: fishing prohibition zone, fishing regulation area, fishing reserve, ecological reserve, marine reserve, marine refuge, integral reserve and marine sanctuary. These terms are obviously not entirely equivalent and the vocabulary used depends on the institutional, cultural or linguistic context. However, for several years, the generic term 'marine protected area' has emerged, in particular in the scientific literature (Allison et al., 1998).

As foreshadowed by the high number of MPAs listed under this generic denomination, the term 'marine protected area' can include extremely different concrete situations. Moreover, in the literature, MPA can take on a different meaning depending on the author, primarily because of the differentiated level of protection offered by the various MPA types. Some see MPAs mainly as zones with restricted or prohibited access on which none or few human uses or disturbances are allowed. Conversely, others see them as zones managed to allow an increased use of the ocean. However, all generally accept the definition suggested by the IUCN in 1994: "any area of the intertidal or subtidal terrain, together with its overlying water and associated flora, fauna, historical and cultural features, which has been reserved by law or other effective means to protect part or all of the enclosed environment" (IUCN, 1988; Kelleher, 1999). One can note that this oft-used definition, in particular in the literature emanating from international institutions, does not answer the question of the breadth and type of the protection offered by MPAs. "To protect the whole or part of the environment thus delimited" can obviously be interpreted in a more or less restrictive way.

The definition of MPA given in the US in the Marine Protected Areas Executive Order 13158 differs very little: "Any area of the marine environment that has been reserved by Federal, State, territorial, tribal or local laws or regulations to provide lasting protection for part or all of the natural and cultural resources therein" (Anon, 2000). If this rather broad definition is followed, a great number of varied sites can be regarded as being MPAs, which is indeed the case in the US where a long series of names can be cited: national marine sanctuaries, fishery management zones, national seashores, national parks, national monuments, critical habitats, national wildlife refuges, national estuarine research reserves, state conservation areas and state reserves.

Other definitions of MPAs or similar concepts are more often founded on zoning within the MPAs, i.e. on the definition of several types of spaces within the same MPA to which graduated specific measures of exclusion or regulation apply. This is the case of the 'biosphere reserves' of the UNESCO's Man and Biosphere (MAB) Programme, which envisages three interdependent zones: a central zone, normally withdrawn from human activities, a buffer zone and a transition zone. The same holds for the Canadian definition of 'national marine conservation areas', a concept used by the specific Canadian law which also stresses zoning: NMCAs "are marine areas managed for a sustainable use. They include sea-bed, the water column and can also include wetlands, estuaries, islands and other coastal lands" (Ministère des Pêches et des Océans, 1999). 
If these two types of definition are combined, a currently frequent type of synthetic definition of MPA surfaces, such as the definition suggested by Alban (2003): “delimited marine spaces to which specific management and conservation measures are applied in order to guarantee a sustainable use of the natural and cultural heritage and inside whose possibly zones of reinforced protection are" or by Guénette et al. (2000a): "Marine Protected Areas (MPAs) refer to management areas in which uses are often regulated by zoning for different activities. MPAs include marine reserves, which are defined as 'no take' areas".

\subsection{A multiform reality}

MPAs can be highly varied in size and form. In the US, for example, small areas such as the Ecological Reserve of Farnsworth Bank in Los Angeles County, California, which covers only 14 acres (5.6 ha) (McArdle, 1997) coexist with large areas such as the National Marine Sanctuary of Monterey Bay, California, which covers 5300 square miles, $\left(13,250 \mathrm{~km}^{2}\right.$ or $\left.1,325,000 \mathrm{ha}\right)$. (National Ocean Service, 2000). In general, the size and the goals of an MPA are related: an exclusion zone of a few hectares, for example, aims to protect a particularly remarkable or endangered element of an ecosystem, while a vast marine national park has multiple uses. Since the 1990s, the trend has rather been to create larger but fewer MPAs, evidence of a shift in how the objectives of MPAs are evolving.

Operation and regulation procedures of these spaces also vary substantially from one MPA to another.

MPAs provide various levels of protection and uses. They vary from sectors where public access is prohibited, such as the Lake Crocodile National Refuge of Fauna in Key Largo, Florida (US Fish and Wildlife Service, 2001) or from sites that allow access but not consumption uses, such as the Edmonds Underwater Park in the State of Washington (Murray, 1998), to sectors where the use of certain specific types of fishing gear are restricted, such as some fishing management areas or to multipurpose protection areas, such as the National Marine Sanctuary of the Keys in Florida (National Ocean Service, 2000).

MPAs also differ in their legal status. Some countries have worked out specific legislation for MPAs - the most notable case is that of Australia. Others have extended the legislation pertaining to terrestrial protected areas such as national parks to the marine field. This may be problematic given the specific characteristics of the marine environment, for example the phenomena related to the marine environment are specific; the permeability of the limits is total, for fish resources as well as for possible pollution; the coastal band concentrates many uses; the marine zones are subject to multiple and often superimposed regulations or administrative qualifications are often very different from terrestrial zones. Others have been based on the legislation relating to fisheries management by added habitat protection legislation as in the case of many MPAs in the United States. ${ }^{2}$

Given the wide variety of MPAs, they can be founded on the basis of a national, federal, territorial or local law or by voluntary agreements. This depends, to a large degree, on the country's legal and constitutional system. In the US, a federal country, some MPAs are located only in federal waters, which, most of the time, extend from 3-200 miles from the shore. These MPAs are controlled under the terms of federal laws by federal agencies. Other MPAs are located only in state waters where federal laws and/or laws of the state can apply. Different MPAs can partially overlap. The Marine National Sanctuary of the Channel Islands ${ }^{3}$ and the National Park of the Channel Islands share their jurisdiction on 
certain parts of oceanic waters. Lastly, some MPAs, such as Cod Cape National Shore, in Massachusetts, include both terrestrial and marine components (Bauman et al., 1998). ${ }^{4}$ In certain countries such as France, the legal status of each element constituting an MPA - tidal zone, water column, seabeds and marine resources - is different.

\section{Evolving goals}

Although they differ in their physical and legal characteristics, MPAs were also established with very different goals in mind. These goals are generally listed in general legal texts on the national status of MPAs or in particular legal texts, drawn up when the MPA was created.

Biscayne National Park is the largest marine park in the American National Parks system, with $95 \%$ of its 173,000 acres (approximately 70,000 ha) in the marine environment. This area received this status in 1968 to preserve and protect for education, inspiration, recreation and enjoyment of present and future generations a rare combination of terrestrial, marine and amphibious life in a tropical setting of great natural beauty. In the same way, Title III of the American Law on marine sanctuaries "authorised federal designation of marine sanctuaries for the purposes of preserving or restoring unique marine environments for their conservation, recreational, ecological or esthetic values" (Guénette et al., 2000a).

This plurality of goals has evolved over time. Two periods stand out: 1970-1980 and 1980-2007.

\subsection{The 1970-1980 period: the primacy of the conservation goal}

Before 1980, one can consider that MPAs had three principal goals: conservation, improvement of scientific knowledge and public education.

\subsubsection{Conservation}

Conservation was the most important objective during this period. With the rise of environmental dangers, protecting areas known as critical habitats, defined as "areas which contain essential species or which have an essential life support function, or which shelter essential ecological processes" (Ray, 1975) was the main concern. Areas such as coral reefs, mangroves and salt-water plants were identified as critical marine habitats which are, in general, related to critical moments (because the latter are a source of vulnerability) of biological cycles: feeding young, mating, spawning, laying eggs and halts on migratory pathways. Such areas were then classified as MPAs, the objective being to preserve representative samples of their biodiversity, to preserve habitats essential to the maintenance of the biological cycle of some species and to maintain in their present state various environments (estuaries, mangroves, coastal marshes) particularly productive from the biological point of view, by preserving these areas from anthropogenic disturbance.

MPAs can also be created with the objective of protecting a particular species rather than a habitat, also known as essential species (Ray, 1975), particularly vulnerable and therefore at risk of extinction. Among these species are whales and dolphins or marine turtles. MPAs then were created especially for protecting any species depending on its 
scarcity, its emblematic or endemic character or its key-species role in ecosystem resilience. Thus, the zone delimited for fishing prohibition located near the Bristol Bay shore off Alaska protects the habitats of the royal crab, an important and valuable resource for this species (Anon, 2000).

Protection can also be related to cultural resources: the National Refuge of Fauna of the Midway atoll protects not only the habitat of endangered species such as the Hawaiian monk seal and coral reefs but also the historical artifacts dating from the famous battle of the Second World War which took place there (US Fish and Wildlife Service, 2001).

Obviously, the question arises of the dimensions necessary for meeting this conservation objective. During the period 1970-1980, the tendency was in favour of a rather reduced dimension for MPAs whose objective was conservation, for the simple reason that creating reserve status with an objective of protection generally requires a 'no take' type of method, i.e. prohibition of removing any resources, which is highly impractical on a large geographical scale. MPAs meeting this aim will, therefore, tend to be modest in size. This is a pledge of the effectiveness of the 'no take' reserves. Guénette et al. (2000a) cite the case of the Seychelles, where "on coral reefs, even small reserves could be efficient at protecting fish targeted by the fishery".

Another size factor of an MPA whose objective is conservation is ecosystem coherence, which has the opposite effect of the preceding factor, mandating preservation of a quantitatively significant share of an ecosystem or habitat. Here already are the elements of a debate that stirred up the MPA literature in the 1990s, the SLOSS (single large or several small) debate, which sought to determine whether it is better to have only one large MPA or several small MPAs.

In the 1970s, continuing this objective of conservation was, for an MPA, nearly synonymous with sanctuarisation, i.e. prohibition of any human activity, not only of fishing. These areas were designed to protect the area from research and exploitation of other marine resources (hydrocarbons, materials, for example) as well as tourism and recreational activities, even any human intrusion (so-called integral reserves) (Menon, 1979).

Generally, during the period 1970-1980, the creation of an MPA necessarily involved prohibiting economic activities inside the MPA, which did not fail to generate conflicts with the aforementioned economic interests. As a report of the Marine Board of the National Research Council (NRC) of the United States (Anon., 1997) states, this type of conflict between economic conservation and interests could be exacerbated "in the future, as the advances in the offshore equipment technology or the changes in the market situation lead to the expansion of coastal populations, marine tourism and recreation and all activities which use or encroach on coastal and marine resources, such as marine fish farming, oil and natural gas drilling at sea, ore exploration and deep water waste dumping. These activities can also conflict with the plans to put sectors such as marine sanctuaries in reserves and to fight against ocean pollution".

\subsubsection{Improvement of scientific knowledge}

The second central objective during the 1970-1980 period, the improvement of scientific knowledge, appears subordinate to the primary objective of conservation. To properly preserve a marine ecosystem, it is necessary to know how it functions. The creation of an MPA is often the occasion to make a preliminary report on the areas by exhaustively listing the biodiversity of the ecosystem or habitat to be preserved. These listings will, in general, confirm the scientific interest of the MPA. 
An MPA can, consequently, become a good place for observation and experimentation because its environment is less disturbed and its limits are clearly defined. For example, it can be used as a pilot, a zone fixed in a certain state of its socioeconomic evolution, usable for comparisons with other zones of the same type but without the same protection. An MPA also makes it possible to more easily observe and determine the local consequences of global change over the medium and long term (for example climate change). An MPA can be a research site, on which the interdisciplinary work of researchers could be done more easily. In fact, MPAs have made it possible to gain better knowledge of the marine environment in general and critical habitats in particular in domains belonging to the fields of biology, ecology, geology, hydrography, etc.

The MPA creation process can also be the occasion to gain better knowledge of the traditional forms of resource use, the local language, the local institutions and policies and, thus, to be better able to include the local communities in the later MPA decision-making processes. This extension of scientific work to the field of social sciences and its transformation in terms of participative governance were rather slow to be set up and in general did not start during this period (Guénette et al., 2000a).

\subsubsection{Public education}

The objective of public education, present from the very start of MPA creation, can be considered a by-product of the conservation objective. MPAs offer clearly important opportunities for the environmental education of the public, distinguishing the general public and the public made up of local communities close to the MPA.

With regard to the first, MPAs are a very useful teaching instrument given their great diversity. Nevertheless, this goal must not disturb the environment. Consequently, integral reserves, located on uninhabited islands, where visitors cannot land (with the exception of scientists), preclude directly viewing these areas but allow films to be made.

With regard to the public made up of the local communities, whose habits and daily practices are often affected when an MPA conservation is set up, it is during the creation process and later management that a teaching dimension can arise: development of an environmental conscience, changes in certain traditional practices (manatee hunting ceased, for example, in Guinea Bissau) or acquired (prohibition of fishing by explosives or poison in the Philippines), internalisation of the sanctions related to the regulation of the MPA. This educational objective can entail specific educational programmes, for example an education and participation programme implemented by small informal groups on the San Salvador Island MPA in the Philippines, which made it possible to increase the population's "ecological and environmental concepts comprehension score from 68-86\% within 14 months" (Guénette et al., 2000a). Pursuing this goal of education toward the local communities was infrequent during the 1970-1980 period.

\subsection{The 1980-2007 period: from conservation to integrated management, changing prospects}

\subsubsection{A change in dominant goals}

During this period, creating MPAs continued to be justified by the goals of conservation, research and education but new goals for the management of fishery resources, recreational activities and tourism development, as well as finally planning and integrated management of coastal areas, appeared more and more clearly. 
As the objective of conservation had been during the previous period, the objective of fisheries management was now, in general, unanimously recognised as a possible dominant MPA objective. During this second period, depending on concrete cases and the preferences of each author and his or her disciplinary field, either fisheries management or the conservation of the marine ecosystems dominated.

On the other hand, the development of other uses that do not involve removing something from the resource, generally seem to be a secondary objective, subordinated to one or the other of the two main goals. There can also be discordance between the theoretical goals attached officially to the creation of an MPA and those that are concretely advanced at the negotiation stage of an MPA project. In this light, development of tourist activities can be a more effective goal to gain adherence of a local community to an MPA project than an acknowledged aim of restrictive management of the fisheries activity.

The educational objective of MPAs was confirmed in the second period, directed at the public, particularly the schools (Rodriguez-Martinez and Ortiz, 1999). However, it is during this period that the educational objective with respect to local communities was developed.

The literature reports that the effort devoted to research in the MPAs is continuing. For example, in West Africa, research on the characteristics of the ichthyological fauna of the Banc d'Arguin (Sevrin-Reyssac and Richer de Forges, 1985). However, the research tasks were also reorientated toward management goals, which made it possible to solve user conflicts by defining the conditions to maintain or even develop the economic activities in an MPA, without compromising the fundamental objective of conservation. Moreover, if this conservation-respecting development is better accepted by local populations from a social point of view, the conditions of the sustainable development are met. The Great Barrier Reef Marine Park is a good example of this type of management, which resulted in a great deal of scientific research (Hundloe, 1985). This MPA includes approximately $95 \%$ of the area of the Great Australian Coral Barrier, which extends over more than 2000 $\mathrm{km}$ of coasts and is currently the largest MPA in the world, with approximately 350,000 $\mathrm{km}^{2}$ (Alban, 2003; Day, 2002). It is "a good example of a combination of two integrated approaches involving small highly protected (or 'no take') marine reserves placed within a larger multi-use management area" (Guénette et al., 2000a).

The first plan of the multi-use management goal was accompanied by the development of research in the social sciences, neglected until then compared with biological sciences (Pomeroy et al., 2006).

\subsection{Appearance of new goals: toward multiple goals}

The results of this research prove that research, conservation and education goals are not incompatible with other uses of the resource, such as fishing, tourism and recreational activities. It suffices to find a management system that allows compromise and compatibility between conservation and development.

This line of thought led to broadening MPAs' goals. Consequently, while continuing to pursue the research, conservation and education goals outlined above, MPAs were recognised during the 1980-2007 period as having other purposes of an economic and recreational nature: the management of fisheries and coastlines and the development of tourism and recreational activities. 


\subsubsection{Fisheries management}

The development of fishing and the protection of fishery resources through MPAs make up one of the most widely discussed topics in the literature, actually an old subject introduced for the first time by Beverton and Holt (1957) but abandoned thereafter for a management approach based on controlling the fleet and fishing gear (Guénette et al., 1998). This topic was included in the 1980s but came to the forefront more thoroughly beginning in 1993, with a particularly abundant literature since 1998 (Boersma and Parrish, 1999; Bohnsack, 1998; Charles and Sanders, 2006; Guénette et al., 2000b; Hall, 1998; Holland and Brazee, 1996; Mangel, 1998; Maury and Gascuel, 1999; Nowlis and Roberts, 1999; Williams, 1998).

These publications have shown that the creation of an MPA is now perceived not as being incompatible with fishing but, rather, as a viable alternative to traditional techniques of fisheries management. For this reason, MPAs can protect reproductive stocks and be a source of new economic development for the nearest zones (e.g. larva exports). They also support the repopulation of the adjacent areas through migration of adult individuals (the spillover effect). They have a function in maintaining the natural age structure of the populations. They preserve biodiversity and protect habitats. They, therefore, support the natural life process of marine species. Moreover, MPAs facilitate monitoring and control activities (Beckley and van der Elst, 1993; Dalzell and Adams, 1995; Rowley, 1994). Smith and Berkes (1991) estimated that well-managed MPAs can be a solution to the crucial problem of free access to resources, well known as 'Tragedy of the Commons' (Hardin, 1968).

MPAs can be considered an insurance policy against the failure of other management modes as part of the principle of precaution (Jones, 1999; Lauck et al., 1998). This step implies knowledge of the fishing methods in the MPA or the future MPA, which requires research. MPAs may have an informational advantage compared with conventional fisheries management measures. This advantage has several facets:

- space-based measurements are easier to understand and, therefore, better accepted from a social point of view (Roberts et al., 2001)

- they require less information (Bohnsack, 1993; Russ and Alcala, 1996)

- controls and monitoring are simplified and, therefore, better respect the MPA's management principles (Roberts and Polunin, 1993).

However, this remains controversial. It can be said that the necessary information before the creation of an MPA is often insufficient (Bohnsack, 1998; Hall, 1998). Nevertheless, it can be argued that MPAs, requiring information exceeding the strict field of fishing, provide a broader view than the conventional means of fisheries management. Similarly, in the MPA's operation phases, adaptive management, which proceeds by trial and error, appears more feasible than conventional fisheries management because the information collected takes many forms (Roberts et al., 1995).

The possibility of developing other activities, such as marine aquaculture, that would not compromise the objective of MPA conservation was also approached, even if this subject remains poorly developed in the literature. 


\subsubsection{Coastal management}

An MPA policy can comprise one of the major features in a global policy of integrated management of coastal resources (Halim and Morcos, 1995). Some authors go even further with the role of MPAs in the governance of the oceans (Costanza et al., 1999; Eichbaum and Agardy, 1995; Hanna, 1999; Lindholm et al., 2001). However, this objective remains insufficiently developed in the literature.

Within the multiple goal definition of an MPA, when provisions for the marine space zoning intervene and a participative management of local communities is institutionalised, it is true that the process of creating an MPA - through its progression, its characteristics and its results - is very similar to littoral and marine area planning. If its goals are achieved, in the medium term the introduction of an MPA initially requires that the various activities present in the zone evolve and that new ones appear.

However, if it is, indeed, space-based management, it is clear that the specificity of marine space, primarily the fact that portions of that space cannot be enclosed in a very dispersive oceanic medium, limits how effective such planning can be. As in fishery matters, this dispersive nature influences the spatial distribution (inward and outward) of the benefits drawn from the MPA. The external influences, such as diffuse or even accidental pollution, can cause vulnerability likely to challenge the effectiveness of the space's management. The relations the coastal band maintains with its surrounding area (in particular if it harbours industrial activities, intensive agriculture or a large urban community) can cancel out a management process of the littoral as a separate portion of space. However, just as the marine ecosystem is an open system in which no physical barrier can be established, MPAs can in no way form an isolated small island of protection (Allison et al., 1998).

\subsubsection{Tourism, eco-tourism and recreational activities}

Studies investigating the relationsships between tourism and MPAs have favoured the appearance of the concept of eco-tourism discussed in the literature (Agardy, 1993; Boyd and Butler, 1996; Deheunynck et al., 2004; Garrod, 2002; Gossling, 1999). Eco-tourism is defined as the subsector of tourism based on environmental protection offering the consumer the direct use of these environmental amenities. It is, primarily, a form of tourism based on viewing and observation, which, in MPAs located in tropical environments, can take the form of scuba diving (in particular on the coral reefs), encounters with marine mammals (whales, orca whales, dolphins, seals), the remote observation of birds, discovery walks or activities of traditional fishing on board traditional boats (such tourist products exist, for example, in the Parc national du Banc d'Arguin ). Gossling (1999) estimated that eco-tourism is a means of safeguarding the biodiversity and the functions of the ecosystems. For tourism to be ecological, it must be based on the use of environmentally respectful equipment and infrastructures, in particular with regard to tourism (e.g. tourists lodging in nomads' tents in the Parc national du Banc d'Arguin). MPAs are particularly appropriate in the development of this subsector which, in turn, can contribute to the sustainable management of MPAs, in particular by providing substitution activities to the communities. 


\section{The evaluation of the effects of MPAs: problems and prospective changes}

The substantial development of MPAs in line with the goals that have been detailed above inevitably raises the question of how to evaluate the effectiveness of these MPAs. It is in general very complicated to evaluate the performance of MPAs with respect to their declared goals, which, as we have seen, are numerous and sometimes contradictory (Weigel et al., 2007). Consequently, this evaluation lacks scientific rigour in certain disciplines. However, the effectiveness of an MPA will depend on the overall interaction of diverse factors over different disciplines, such as the biogeophysical features of the MPA, the biological characteristics of the protected species or ecosystems, the socioeconomic factors (the scale of various human activities, conflicts between uses), the selected modes of management (top-down or participative), the legal and institutional framework, etc. Obviously, any evaluation step assumes that a sufficiently extensive database is available.

\subsection{Methods: from monetary valuations to indicators}

The economic valuation is well known and among the most widely used. It is not specific to the field of MPAs and is possible for any non-market element of the environment and the natural capital (Garrod, 2002). It uses specific methods (the contingent valuation method, the travel costs method, the hedonic prices method) relying on the willingness to pay of economic agents, assumed to be a good expression of their preferences, to evaluate monetarily the benefits or the damage received or undergone by these agents. However, these various methods themselves are debatable and the attempts to give a value in monetary terms to non-market benefits (economic value of living resources and environmental services) have often been criticised (Dixon, 1993; Faucheux and Noël, 1995).

Other than monetary evaluation, indicators reflecting the changes in the state of the natural environment and the socioeconomic conditions of the concerned communities can also be used. The problem with indicators is not specific to MPAs and an abundant literature devoted to environmental indicators in general has long listed the features necessary for an indicator to be usable in an evaluation process (Belfiore et al., 2003; Ehler, 2003; Linton and Warner, 2003).

A list more specifically devoted to the indicators that are usable in evaluating the effectiveness of MPAs was provided by Pomeroy et al. (2004). The list comprises 44 indicators that have already been used on 11 pilot MPA sites. They include three groups of indicators: environmental indicators, socioeconomic indicators and governance indicators. Generally, environmental indicators are well developed but socioeconomic and governance indicators are somewhat less often treated (Bowen and Riley, 2003; Garcia et al., 2000; Hockings et al., 2000).

\subsection{Results are difficult to establish}

\subsubsection{MPAs' ecological effects}

The study of the spatial component of ecological benefits (refuge effect, transfer effect) has attracted the attention of research in the literature more than the temporal effect (buffer effect). A study on 100 reserves shows an average growth of $91 \%$ in the number of fish, 
$31 \%$ in fish size and $23 \%$ in the number of species. However, the results seem to vary considerably with the species, how intensely they are being removed from the environment and how long the MPA has carried out its protective function. To date, the transfer effect seems much more difficult to demonstrate. On the other hand, the cascade effect, a modification of the trophic chains leading to a proliferation of invasive species, in particular predators, can appear and challenge the MPA's capacity to restore the ecosystem to a level identical with a past period.

\subsubsection{Effects of MPAs on fisheries}

A significant part of the literature evaluating the benefit of MPAs relates to fisheries. It is extremely difficult to prove that fish captures have increased (Crowder et al., 2000; Forgarty et al., 2000; Schmidt, 1997; Shipp, 2002; Willis et al., 2003). Only three studies (Goodridge et al., 1997; Roberts et al., 2001; Russ and Alcala, 1996), on a Filipino reserve for the Russ and Alcala study and a reserve in Saint Lucia (in the Caribbean) for the other two, showed an increase in the captures per unit of effort (CPUE) in the adjacent area when there was an MPA. However, cases increasing the fishing effort on the adjacent zones (Gulf of Mexico Fishery Management Council, 1999; Parrish, 1999) or a concentration of fishermen at the borders of an MPA can also be noted (Dobrzynski and Nicholson, 2000; Hannesson, 1998; Kelly et al., 2002).

The results in terms of fishing management costs also are discussed. If the cost of control appears lower in general in MPAs than in the conventional modes of fisheries management (Armstrong and Reithe, 2001) and some support the opposite claim (Parrish, 1999). Finally, the informational advantage often argued in favour of MPAs also appears ambiguous: in practice, the insufficiency of the data obliterates what appears to be an essentially theoretical advantage.

\subsubsection{Effects of MPAs on tourism}

Meeting the objective of developing eco-tourism activities is certainly entirely within the range of an MPA, once the validity of this type of objective is recognised. Indeed, the literature abounds with examples showing an increase in tourist numbers following the creation of an MPA which, by an image or mirror effect, increases in value with the influx of tourists and the environmental features most likely to attract them. As for terrestrial natural parks, this powerful attraction is obviously exploited by the professionals of the tourist industry. Thus, the Marine Park of the Great Coral Barrier in Australia has become a must for tourists (Kenchington, 1991). The Japanese marine parks increasingly resemble amusement parks. Visitors pass from one to another.

The increase in tourist numbers (generally more sensitive in MPAs in the temperate zones than in the tropical zones, often because the latter have insufficient tourism infrastructures) can turn into a problem of congestion involving the appearance of negative externalities of the tourist activity on the ecosystem. Even eco-tourism activities, a priori non-extractive activities, can have, if they are poorly managed, negative effects on ecosystem health. The impacts of scuba diving, for example, were the subject of many articles: degradation of the coral and fish and marine mammal feeding (Bohnsack, 1998b; Davis and Tisdell, 1995; Harriot et al., 1997; Schaeffer et al., 1999). Likewise, simply observing animals can stress them (Mazaudier and Michaud, 2000; Weaver, 2002). In any assumption, the load capacity of the ecosystem taken in the broad sense, i.e. both biological and social, must be respected by the definition of sustainable tourism ${ }^{6}$ within an MPA. 


\subsubsection{Effects on local communities}

MPAs can have negative effects on the neighboring communities or those located in MPAs. These effects can be socioeconomic (negative modifications of fishing or other activities) and, even more often, sociocultural. On the one hand, the economic effects of tourism are often unequally and inequitably distributed (Hough, 1988). In addition, the effects of tourism as regards artificialisation of the local culture and dispossession of a way of life are also well known (Hoagland et al., 1995; Sanchirico et al., 2002) These impacts of unequal distribution (often immediate costs concentrate on very few losers and future benefits on many dispersed winners) must be accompanied by compensatory measures, by supporting substitution activities if fishing activities are disturbed, for example, or the social acceptability of the MPA might very well be challenged. These compensations also make it possible to come to terms with the temporal discordance between the immediate costs and the future benefits of the MPA. Similarly, these compensation measures can take very diverse concrete forms:

- monetary compensation - help with reconversion or diversification, in particular in eco-tourism activities

- construction of infrastructures, in particular ports

- development of alternate fisheries

- provision of user rights or territorial exclusivity.

These can be both the means and the object of a negotiation leading to participative management. As the survey carried out by Guénette et al. (2000a) shows, it is only recently that institutions designed to support the expression of the indigenous peoples within MPAs have truly begun to be set up with relative success.

\section{Conclusion}

Until 1980, creation of MPAs favoured the goals of conservation, scientific research and education. However, the increasing conflicts between users and wardens and the resulting confrontations did not encourage meeting the goals of MPAs, in particular in terms of conservation, because users and residents generally did not comply with the rules laid down for MPA management. These failures led to a reflection on a change in strategy, so as to better integrate users' concerns into the functions reserved for MPAs.

Beginning in the 1980s, broadening MPAs' goals resulted from the need to integrate human needs into the MPA concept, the only way to resolve conflicts between the MPA and economic activities. In practice, this integration took two forms: MPAs specialising and taking on multiple functions. In the first case, this resulted in creating MPAs reserved for biodiversity and habitat conservation, MPAs for the development of fishing and the protection of maritime resources and MPAs for tourism and education, etc. In the second case, this resulted in either ceasing the presumably incompatible activities while zoning certain areas for conservation and others for economic and recreational activities such as tourism and sport fishing or working out a management system allowing MPAs to ensure the compatibility of all these goals in a single area.

Thus, since the 1980s, the multifunctional nature of MPAs has been taken into account. The reconciliation of the various functions of MPA has been made possible by 
reorienting research activities, from the initial conservation objective toward the broader management objective of sustainable development. From now on, MPAs are not solely regarded as tools for exclusion but as management tools for economic activities. Their management, which was centralised at the beginning, is now based on the principle of participative governance, a progression that today supports the capacity of developing a plurality of activities within MPAs without compromising their conservation function (Weigel et al., 2007).

Herein lies an essential element for ensuring the sustainable development of the marine coastal zones. The plurality of MPAs' goals, indeed, responds to the triple character of any sustainable development, which must simultaneously be ecological, economic and social.

\section{References}

Agardy, T. (1993) 'Accommodating ecotourism in multiple use planning of coastal and marine protected areas', Ocean and Coastal Management, Vol. 20, No. 3, pp.219-239.

Alban, F. (2003) Contribution à l'analyse économique des aires marines protégées. Application à la rade de Brest et à la mer d'Iroise, Thèse de Doctorat, mention Sciences économiques, Ecole doctorale des Sciences de la mer, UBO, December, p.291.

Allison, G.W., Lubchenco, J. and Carr, M.H. (1998) 'Marine reserves are necessary but not sufficient for marine conservation', Ecological Applications, Vol. 8, No. 1 (supplement), pp.579-592.

Anon. (1997) Striking a Balance. Improving Stewardship of Marine Areas, Washington, DC: National Academy Press.

Anon. (2000) Code of Federal Regulations, 50 CFR 622, 35(c), Federal Register, Vol. 65, Chap. 105), Washington, DC: US Government Printing Office.

Armstrong, C.W. and Reithe, S. (2001) 'Comment: marine reserves, will they accomplish more with management costs?', Marine Resource Economics, Vol. 16, No. 2, pp.165-175.

Baumann, C., Brody, S., Fenton, D. and Nicholson, B. (1998) A GIS Database of Existing Coastal and Marine Protected Areas, Conservation Zones, and Restricted Fishing Areas in the Gulf of Maine, Council of the Gulf of Maine.

Beckley, L. and van der Elst, R.P. (Ed.) (1993) 'Fish, fishers and fisheries', Proceedings of the Second South African Marine Linefish Symposium, held in Durban 23-24 October 1992, pp.45-51, Durban South Africa: Oceanographic Research Institute.

Belfiore, S., Balgos, M., McLean, B., Galofre, J., Blaydes, M. and Tesch, D. (2003) 'A reference guide on the use of indicators for integrated coastal management', IOC Manuals and Guides, Paris, France: 45 UNESCO, p.127.

Beverton, R.J.M. and Holt, S.J. (1957) 'On the dynamics of exploited fish populations', Fish. Invest. Minist. Agric. Fish Food G.B. (2 Sea Fish), Vol. 19, p.533.

Boersma, P.D. and Parrish, J.K. (1999) 'Limiting abuse: marine protected areas, a limited solution', Ecological Economics, Vol. 31, No. 2, pp.287-304.

Bohnsack, J.A. (1993) 'Marine reserves: they enhance fisheries, reduce conflicts and protect resources', Oceanus, Vol. 36, No. 3, pp.63-71.

Bohnsack, J.A. (1998) 'Application of marine reserves to reef fisheries management', Australian Journal of Ecology, Vol. 23, No. 3, pp.298-304.

Bowen, R.E. and Riley, C. (2003) 'Socio-economic indicators and integrated coastal management, Ocean and Coastal Management, Vol. 46, No. 3, pp.299-312.

Boyd, S.W. and Butler, R.W. (1996) 'Managing ecotourism: an opportunity spectrum approach', Tourism Management, Vol. 17, No. 8, pp.557-566. 
Charles, A. and Sanders, J. (2006) 'Issues arising on the interface of MPAs and fisheries management', A report for the FAO, Rome, June 2006.

Costanza, R., Andrade, F., Antes,P., van de Belt, M., Boesch, D., Boersma, P.D., Catarino, F., Hanna, S., Limburg, K., Low, B., Molitor, M., Pereira, J.G., Rayner, S., Santos, R., Wilson, J.A. and Young, M.D. (1999) 'Ecological economics and sustainable governance of the oceans', Ecological Economics, Vol. 31, No. 2, pp.171-187.

Crowder, L.B., Lyman, S.J., Figueira, W.F. and Priddy, J. (2000) 'Source-sink population dynamics and the problem of siting marine reserves', Bulletin of Marine Science, Vol. 66, No. 3, pp.799-820.

Dalzell, P. and Adams, T.J.H. (1995) South Pacific Commission and Forum Fisheries Agency Workshop on the Management of South Pacific Inshore Fisheries. Noumea, New Caledonia, South Pacific.

Davis, D. and Tisdell, C. (1995) 'Recreational scuba-diving and carrying capacity in marine protected areas', Ocean and Coastal Management, Vol. 26, pp.19-40.

Day, J. (2002) 'Zoning lessons from the Great Barrier Reef Marine Park', Ocean and Coastal Management, Vol. 45, Nos 2/3, pp.139-156.

Deheunynck, A., Da Silva, A.S., Biai, J., Mohamed Ould Saleck, A., Ould Mohamed Saneh, M. and Diémé, S. (2004) 'L'écotourisme dans les aires marines protégées d'Afrique de l'Ouest: bilan et modalités d'une alternative de développement et de politique publique', Dakar, IRD/IUCN/PNBA/DPN, Ref: CONSDEV Working document/WP6/01.

Dixon, J.A. (1993) 'Economic benefits of marine protected areas', Oceanus, Vol. 36, No. 3, pp.35-40.

Dobrzynski, T. and Nicholson, E. (2000) 'An evaluation of the short-term social and economic impacts of marine reserves on user groups in Key West', Environmental Defense, New York, p. $162+$ annexes.

Ehler, N. (2003) 'Indicators to measure governance performance in integrated coastal management', Ocean and Coastal Management, Vol. 46, pp.335-345.

Eichbaum, W.M. and Agardy, T. (1995) 'The role of marine protected areas in comprehensive marine governance', Proceedings of the Second International Symposium and Workshop on Marine and Coastal Protected Areas: Integrating Science and Management, Washington, DC, Office of Ocean and Coastal Resource Management, NOAA and the US Man and the Biosphere Program.

Faucheux, S. and Noël, J-F. (1995) Economie des Ressources Naturelles et de l'Environnement, Paris: Armand Colin

Fogarty, M.J., Bohnsack, J.A. and Dayton, P.K. (2000) 'Marine reserves and resource management', in C. Sheppard (Ed.), Seas at the Millennium: an environmental evaluation, Elsevier, pp.375-392.

Garcia, S.M., Staples, D.J. and Chesson, J. (2000) 'The FAO guidelines for the development and use of indicators for sustainable development of marine capture fisheries and an Australian example of their application', Ocean and Coastal Management, Vol. 43, pp.537-556.

Garrod, B. (2002) 'Monetary valuation as a tool for planning and managing ecotourism', International Journal of Sustainable Development, Vol. 5, No. 3. pp.351-371.

Goodridge, R. et al. (1997) 'Changes in the shallow reef fishery associated with implementation of a system of fishing priority and marine reserve areas in Soufrière, St. Lucia', Proceedings of the Gulf and Caribbean Fisheries Institute, Christ Church (Barbados), November 1996, Vol. 49, pp.316-353.

Gossling, S. (1999) 'Ecotourism : a means to safeguard biodiversity and ecosystem functions?', Ecological Economics, Vol. 29, No. 2, pp.303-320.

Guénette, S., Chuenpagdee, R. and Jones, R. (2000a) 'Marine protected areas with an emphasis on local communities and indigenous peoples: a review', Fisheries Center Research Reports, Vol. 8, No. 1, p.57. 
Guénette, S., Lauck, T. and Clark, C. (1998) 'Marine reserves: from Beverton and Holt to the present', Reviews in the Fish Biology and Fisheries, Vol. 8, pp.251-272.

Guénette, S., Pitcher, T.J. and Walters, C.J. (2000b) 'The potential of marine reserves for the management of northern cod in Newfoundland', Bulletin of Marine Science, Vol. 66, No. 3 , pp.831-852.

Gulf of Mexico Fishery Management Council (1999) Marine reserves technical document, A scoping document for the Gulf of Mexico, NOAA, Tampa, Florida, p.41.

Halim, Y. and Morcos, S. (Ed.) (1995) Workshop on Oceanographic Input to Integrated Coastal Zone Management in the Red Sea and Gulf of Aden, Jeddah, Saudi Arabia, 8 October 1995, Paris, France: Unesco.

Hall, S.J. (1998) 'Closed areas for fisheries management - the case consolidates', Trends in Ecology and Evolution, Vol. 13, No. 8, pp.297-298.

Hanna, S. (1999) 'Strengthening governance of ocean fishery resources', Ecological Economics, Vol. 31, No. 2, pp.275-286.

Hannesson, R. (1998) 'Marine reserves: what would they accomplish?', Marine Resource Economics, Vol. 13, No. 3, pp.159-170.

Hardin, G. (1968) 'The tragedy of the commons', Science, Vol. 162, No. 3859, pp.1243-1248.

Harriot,V.J., Davis, D. and Banks, S.A. (1997) 'Recreational diving and its impacts in marine protected areas in Eastern Australia', Ambio, Vol. 26, No. 3, pp.173-179.

Hoagland, P., Kaoru, Y. and Broadus, J.M. (1995) A Methodological Review of Net Benefits Evaluation for Marine Reserves, World Bank, Environmental Economics Series, paper No. 027, p.69.

Hockings, M., Stolton, S. and Dudley, N. (2000) Evaluating Effectiveness: a Framework for Assessing the Management of Protected Areas, Gland, Switzerland and Cambridge, UK, IUCN, p.121.

Holland, D.S. and Brazee, R.J. (1996) 'Marine reserves for fisheries management', Marine Resource Economics, Vol. 11, No. 3, pp.157-171.

Hough, J.L. (1988) 'Obstacles to effective management conflicts between national parks and surrounding human communities in developing countries', Environmental Conservation, Vol. 15, No. 2, pp.129-136.

Hundloe, T.J. (1985) 'Fisheries of the Great Barrier Reef', Spec. Publ. Ser. Great Barrier Reef Marine Park Authority, Vol. 2, p.158.

IUCN (1988) The World Conservation Union', Resolution 17.38 of the 17th General Assembly of the IUCN, Gland, Switzerland and Cambridge, UK, IUCN.

Jones, P.J.S. (1999) 'Marine nature reserves in Britain: past lessons, current status and future issues', Marine Policy, Vol. 23, Nos. 4-5, pp.375-396.

Kelleher, G. (1999) Guidelines for Marine Protected Areas, World Commission on Protected Areas, IUCN - WCU, Gland, Suisse, p.107.

Kelleher, G., Bleakley, C. and Wells, S. (1995) A Global Representative System of Marine Protected Areas, Vol. 1: Antarctic, Arctic, Mediterranean, Northwest Atlantic, Northeast Atlantic and Baltic, (p.241), Vol. 2: Wider Caribbean, West Africa and South Atlantic, (p.99), Washington, DC, USA: World Bank.

Kelly, S., Scott, D. and MacDiarmid, A.B. (2002) 'The value of spillover fishery for spiny lobster around a marine reserve in Northern New Zealand', Coastal Management, Vol. 30, No. 2, pp.153-166.

Kenchington, R. (1991) 'Tourism development in the Great Barrier Reef Marine Park', Ocean and Shoreline Management, Vol. 15, pp.57-78.

Lauck, T., Clark, C.W., Mangel, M. and Munro, G.R. (1998) 'Implementing the precautionary principle in fisheries management through marine reserves', Ecological Applications, Vol. 8, No. 1, pp.S72-S78.

Lindholm, D.M., Auster, P.J., Ruth, M. and Kaufman, L. (2001) 'Modeling the effects of fishing and implications for the design of marine protected areas: juvenile fish responses to variations in seafloor habitat', Conservation Biology, Vol. 15, No. 2, pp.424-437. 
Linton, D.M. and Warner, G.F. (2003) 'Biological indicators in the Caribbean coastal zone and their role in integrated coastal management', Ocean and Coastal Management, Vol. 46, No. 3, pp.261-276.

Mangel, M. (1998) 'No-take areas for sustainability of harvested species and a conservation invariant for marine reserves', Ecology Letters, Vol. 1, No. 2, pp.87-90.

Maury, O.and Gascuel, D. (1999) 'SHADYS, a GIS based numerical model of fisheries. Example application the study of a marine protected area', Aquatic Living Resources, Vol. 12, No. 2 , pp.77-88.

Mazaudier, L. and Michaud, J.C. (2000) 'Gestion des activtés d'observation des mammifères marins: quelques études de cas', Revue de l'Université de Moncton, No. hors série, pp.55-80.

McArdle, D.A. (1997) 'Marine protected areas should be managed with greater integration', California Agriculture, Vol. 51, No. 4, pp.33-34.

Menon, A.G.K. (1979) 'A proposal for the establishment of a national marine park in the western Indian Ocean', Environmental Conservation, Vol. 6, No. 2, pp.151-152.

Ministère Pêches et Océans (1999) 'La création d'aires marines protégées', Une démarche concertée, Gouvernement Canada, Ottawa, p.10.

Murray, S.N. (1998) 'Effectiveness of marine life refuges on southern California shores. California and the World Ocean '97', in O.R. Magoon, H. Converse, B. Baird, and M. Miller-Henson (Eds.), Taking a Look at California's Ocean Resources: An Agenda for the Future, Reston: ASCE Vol. 2, pp.1453-1465.

N'Diaye, Ch., Bassène, Cl. and Weigel, J.Y. (2002) 'Bibliography on Marine Protected Areas. General and regional references for West Africa', Dakar, IRD, Ref: CONSDEV Working Document/WP1/03, p.3437.

National Ocean Service (2000) (National Oceanic and Atmospheric Administration) 'Sustaining coastal and marine resources for future generations: a status report', Renewable Resources Journal, Vol. 18, No. 2, pp.10-14.

Nowlis, J.S. and Roberts, C. (1999) 'Fisheries benefits and optimal design of marine reserves', Fishery Bulletin, Vol. 97, No. 3, pp.604-616.

Parrish, R. (1999) 'Marine reserves for fisheries management: why not?', Calif. Coop. Oceanic Fisheries Investigation Reports, Vol. 40, pp.77-86.

Pomeroy, R.S., Mascia, M.B. and Pollnac, R.B. (2006) 'Marine Protected Areas: The Social Dimension', a report for the FAO Workshop on MPAs and Fisheries Management, Rome, Italy, June 12-14 2006.

Pomeroy, R.S., Parks, J.E. and Watson, L.M. (2004) How is Your MPA Doing ? A Guidebook of Natural and Social Indicators for Evaluating Marine Protected Area Management Effectiveness, Gland, Switzerland and Cambridge, UK: IUCN pp.xvi + 216.

Ray, G.C. (1975) 'Critical marine habitats: definition, description, criteria and guidelines for identification and management', Proceedings of an International Conference on Marine Parks and Reserves, May 12-14, Tokyo, Japan, Gland, Switzerland: IUCN.

Roberts, C.M. and Polunin, N.V.C. (1993) 'Marine reserves: simple solutions to managing complex fisheries?', Ambio, Vol. 22, No. 6, pp.363-368.

Roberts, C.M., Ballantine, W.J., Buxton, C.D., Dayton, P., Crowder, L.B., Milon, W., Orbach, M.K., Pauly, D., Trexler, J. and Walters, C.J. (1995) Review of the use of marine fishery reserves in the US Southeastern Atlantic, NOAA, Technical Memorandum MNSF-SEFSC-376, Miami, Florida, p.40.

Roberts, C.M., Bohnsack, J.A., Gell, F., Hawkins, J.P. and Goodridge, R. (2001) 'Effects of marine reserves on adjacent fisheries', Science, Vol. 294, No. 5548, pp.1920-1923.

Rodriguez-Martinez, R. and Ortiz, L. (1999) 'Coral reef education in schools of Quintana Roo, Mexico', Ocean and Coastal Management, Vol. 42, No. 12, pp.1061-1068.

Rowley, R.J. (1994) 'Marine reserves in fisheries management', Aquatic Conservation: Marine and Freshwater Ecosystems, Vol. 4, pp.233-254. 
Russ, G.R. and Alcala, A.C. (1996) 'Do marine reserves export adult fish biomass? Evidence from Apo Island, central Philippine', Marine Ecology Progress Series, Vol. 132, pp.1-9.

Sanchirico, J.N., Cochran, K.A. and Emerson, P.M. (2002) Marine Protected Areas: Economic and Social Implications, Washington, DC: WWF.

Schaeffer, T.N., Foster, M.S., Mandrau, M.E. and Walker, R.K. (1999) 'Diver disturbance in kelp forests', California Fish and Game, Vol. 85, No. 4, pp.170-176.

Schmidt, K.F. (1997) 'No-take zone Spark fisheries debate', Science, Vol. 277, No. 5325, pp.489-491.

Sevrin-Reyssac, J. and Richer de Forges, B. (1985) 'Particularités de la faune ichtyologique dans un milieu sursalé du Parc national du Banc d'Arguin (Mauritanie)', Cahiers ORSTOM, Série Océanographie, Vol. 20, No. 1, pp.85-99.

Shipp, R.L. (2002) 'No-take marine protected areas, as a fishery management tool, in a pragmatic perspective', a report to the Fish America Foundation, p.8.

Silva, E.M., Gately, E.M. and Desilvestri, I. (1986) 'A bibliographical listing of coastal and marine protected areas: a global survey’, Woods Hole Oceanographic Institution Technical Report, WHOI-86-11.

Smith, A. and Berkes, F. (1991) "Solutions to the "Tragedy of the Commons": sea-urchin management in St Lucia, West Indies', Environmental Conservation, Vol. 18, No. 2, pp.131-136.

US Fish and Wildlife Service (2001) National Wildlife Refuge System, available from: www.refuges.fws.gov.

Weaver, D.B. (2002) 'The evolving concept of ecotourism and its potential impacts', International Journal of Sustainable Development, Vol. 5, No. 3, pp.251-264.

Weigel, J-Y. and Sarr, O. (2002) Bibliographical Analysis of Marine Protected Areas, Dakar, IRD, Ref: CONSDEV Synthesis/WP1/02, p.21.

Weigel, J-Y., Féral, F. and Cazalet, B. (Eds.) (2007) Les aires marines protégées d'Afrique de l'Ouest. Gouvernance et politiques publiques, Perpignan: Presses Universitaires de Perpignan, p.232.

Williams, M. (1998) 'Do fisheries and marine protected areas need each other?', Parks, Vol. 8, No. 2, pp.47-53.

Willis, T.J., Millar, R.B., Babcock, R.C. and Tolimieri, N. (2003) 'Burdens of evidence and the benefits of marine reserves: putting Descartes before des horse?', Environmental Conservation, Vol. 30, pp.97-103

\section{Notes}

1 Project INCO-DEV "CONSDEV" (ICA-4-2001-10043) and Project "ECOST" (INCO-CT-2005-003711)

2 They also have a specific legislation included in the US Marine Protection, Research and Sanctuaries Act of 1972. Under the terms of this law, it is the NOAA federal administration that is responsible for preparing the creation of MPAs, which are formally created after approval by the President of the United States.

3 The Channel Islands National Marine Sanctuary is located 25 miles from the coast of Santa Barbara, California.

4 In the US, to establish an MPA inventory, a collection of elaborated functional criteria was based on the presence of five principal terms appearing in the definition of an MPA given by the executive order: 'area', 'reserve', 'marine', 'permanent' and 'protection'.

5 Term coined by Garrett Hardin (1968).

6 For the contrary opinion, according to which eco-tourism, like any form of tourism, is not sustainable, see Clarke, 2002. 